\title{
Spatial, temporal, and vertical variability of polar stratospheric ozone loss in the Arctic winters 2004/2005-2009/2010
}

\author{
J. Kuttippurath, S. Godin-Beekmann, F. Lefèvre, and F. Goutail \\ UPMC Université Paris 06, Université Versailles-Saint-Quentin, UMR 8190 LATMOS-IPSL, CNRS/INSU, Paris, France
}

Received: 10 May 2010 - Published in Atmos. Chem. Phys. Discuss.: 15 June 2010

Revised: 5 October 2010 - Accepted: 8 October 2010 - Published: 20 October 2010

\begin{abstract}
The polar stratospheric ozone loss during the Arctic winters 2004/2005-2009/2010 is investigated by using high resolution simulations from the chemical transport model Mimosa-Chim and observations from Aura Microwave Limb Sounder (MLS), by applying the passive tracer technique. The winter 2004/2005 shows the coldest temperatures, highest area of polar stratospheric clouds and strongest chlorine activation in 2004/2005-2009/2010. The ozone loss diagnosed from both simulations and measurements inside the polar vortex at $475 \mathrm{~K}$ ranges from $0.7 \mathrm{ppmv}$ in the warm winter $2005 / 2006$ to $1.5-1.7 \mathrm{ppmv}$ in the cold winter 2004/2005. Halogenated (chlorine and bromine) catalytic cycles contribute to $75-90 \%$ of the ozone loss at this level. At $675 \mathrm{~K}$ the lowest loss of $0.3-0.5 \mathrm{ppmv}$ is computed in $2008 / 2009$, and the highest loss of 1.3 ppmv is estimated in $2006 / 2007$ by the model and in $2004 / 2005$ by MLS. Most of the ozone loss (60-75\%) at this level results from nitrogen catalytic cycles rather than halogen cycles. At both 475 and $675 \mathrm{~K}$ levels the simulated ozone and ozone loss evolution inside the vortex is in reasonably good agreement with the MLS observations. The ozone partial column loss in 350-850 K deduced from the model calculations at the MLS sampling locations inside the polar vortex ranges between 43 DU in 2005/2006 and 109 DU in 2004/2005, while those derived from the MLS observations range between 26DU and $115 \mathrm{DU}$ for the same winters. The partial column ozone depletion derived in that vertical range is larger than that estimated in $350-550 \mathrm{~K}$ by $19 \pm 7 \mathrm{DU}$ on average, mainly due to $\mathrm{NO}_{\mathrm{x}}$ chemistry. The column ozone loss estimates from both Mimosa-Chim and MLS in 350-850 K are generally in good agreement with those derived from ground-based ultravioletvisible spectrometer total ozone observations for the respective winters, except in 2010.
\end{abstract}

Correspondence to: J. Kuttippurath (jayan@aero.jussieu.fr)

\section{Introduction}

Unlike in the Antarctic winter stratosphere, the chemical ozone loss in the Arctic is highly variable. This variability is primarily caused by the variations in Arctic meteorology. That is, the Arctic stratosphere is often disturbed by planetary wave forcing triggered by mountain orography that disrupts the unstable polar vortex in most winters. Therefore, the Arctic experiences high extreme cold as well as sudden stratospheric warmings (SSWs) at times. As a result the degree of ozone loss is mostly controlled by the strength of the vortex and magnitude of air temperature within. For instance, the winters 1995, 1996, 2000, and 2005 were very cold and the cumulative total ozone loss was as high as $\sim 25-$ 35\% (Rex et al., 2006; WMO, 2007; Goutail et al., 2005). On the other-hand, the winters 1997, 1998, 1999, 2001, 2002, 2006, and 2009 were relatively warm and the loss was minimal, about 10-15\%, while the winters 2003, 2007, and 2008 were moderately cold and hence, the loss was in an average scale of about 15-20\% (WMO, 2007; Goutail et al., 2010).

Significant improvements have been made in understanding the chemistry of ozone loss in the polar lower stratosphere in the last decade. Studies suggest that very low temperatures $(<195 \mathrm{~K})$ initiate the formation of Polar Stratospheric Clouds (PSCs), and chlorine activation on these PSCs triggers the ozone depletion when the sun returns over the Arctic in spring. The halogen cycles $\mathrm{ClO}-\mathrm{ClO}$ and $\mathrm{BrO}-$ $\mathrm{ClO}$ contribute about $80-90 \%$ of ozone loss in this region through the above-said processes (WMO, 2007). However, ozone loss at higher altitudes is driven by different chemical cycles than those discussed in the lower stratosphere. A detailed study on the ozone loss process at higher altitudes is still lacking. The available studies deal with specific issues of mid-winter warming and concomitant mid-latitude ozone loss (for e.g. Grooß et al., 2005a; Vogel et al., 2008). None of these studies perform a detailed analysis of the winter stratosphere in different conditions to diagnose the contribution

Published by Copernicus Publications on behalf of the European Geosciences Union. 
of relevant cycles to the ozone loss in a concluding manner. Although the study by Konopka et al. (2007) deal with more than one winter, it is limited to a box model rather than a fullchemistry three dimensional model. Therefore, a comprehensive study is warranted on the subject to characterise the contribution of various chemical cycles in the polar stratosphere in different meteorological conditions. The recent six winters were entirely different in this regard, which provide a perfect platform to perform such a study. So in this paper, we examine the ozone loss and its driving chemical cycles (up to $850 \mathrm{~K}$ isentropic level) for the recent winters 2005-2010 and assess the variability of ozone loss in a quantitative perspective using simulations and measurements. Calculations using a high resolution chemical transport model (CTM) together with satellite observations are exploited for this purpose.

The article is organised as follows: After Introduction, the model, measurements and meteorological situation of the studied winters are presented in Sect. 2-4. The simulations of ozone, ozone loss, chlorine monoxide $(\mathrm{ClO})$ and their comparison with observations for the recent winters are described in Sect. 5. The simulated ozone loss and production rates, contribution of different chemical cycles to the ozone loss and the ozone column loss during the winters are analysed in Sect. 6. Section 7 briefs the conclusion of the study.

\section{The simulations with Mimosa-Chim CTM}

The Mimosa-Chim CTM has been successfully used for the diagnosis of polar ozone loss in previous winters (Kuttippurath et al., 2009; Tripathi et al., 2007, 2006) and is described in detail in Tripathi et al. (2006). The model combines the Mimosa advection code (Hauchecorne et al., 2002) with the REPROBUS chemistry scheme (Lefèvre et al., 1994). The model has a horizontal resolution of $1^{\circ} \times 1^{\circ}$. It has isentropic vertical coordinates on 25 levels, resolved by $5 \mathrm{~K}$ in the lower stratosphere. Winds and temperatures are taken from the European Centre for Medium Range Weather Forecasts (ECMWF) operational analyses. The diabatic transport through the isentropes is computed from the heating rate calculations by MIDRAD (Shine, 1987), driven by climatological $\mathrm{H}_{2} \mathrm{O}, \mathrm{CO}_{2}$ and by the $\mathrm{O}_{3}$ fields calculated by MimosaChim.

The model includes a comprehensive description of stratospheric chemistry. Absorption cross-sections and kinetics data are based on Sander et al. (2006). The absorption crosssections of $\mathrm{Cl}_{2} \mathrm{O}_{2}$ are taken from Burkholder et al. (1990) and are extrapolated to $450 \mathrm{~nm}$. They are in very good agreement with the most recent $\mathrm{Cl}_{2} \mathrm{O}_{2}$ spectrum measurements by Papanastasiou et al. (2009). Monthly varying $\mathrm{H}_{2} \mathrm{SO}_{4}$ fields leading to the formation of liquid aerosols in the CTM are computed from the outputs of a 2-D-model long-term simulation, which considers the impacts of volcanic eruptions. The heterogeneous chemistry contains reactions on binary and ternary liquid aerosols, nitric acid trihydrate (NAT), and

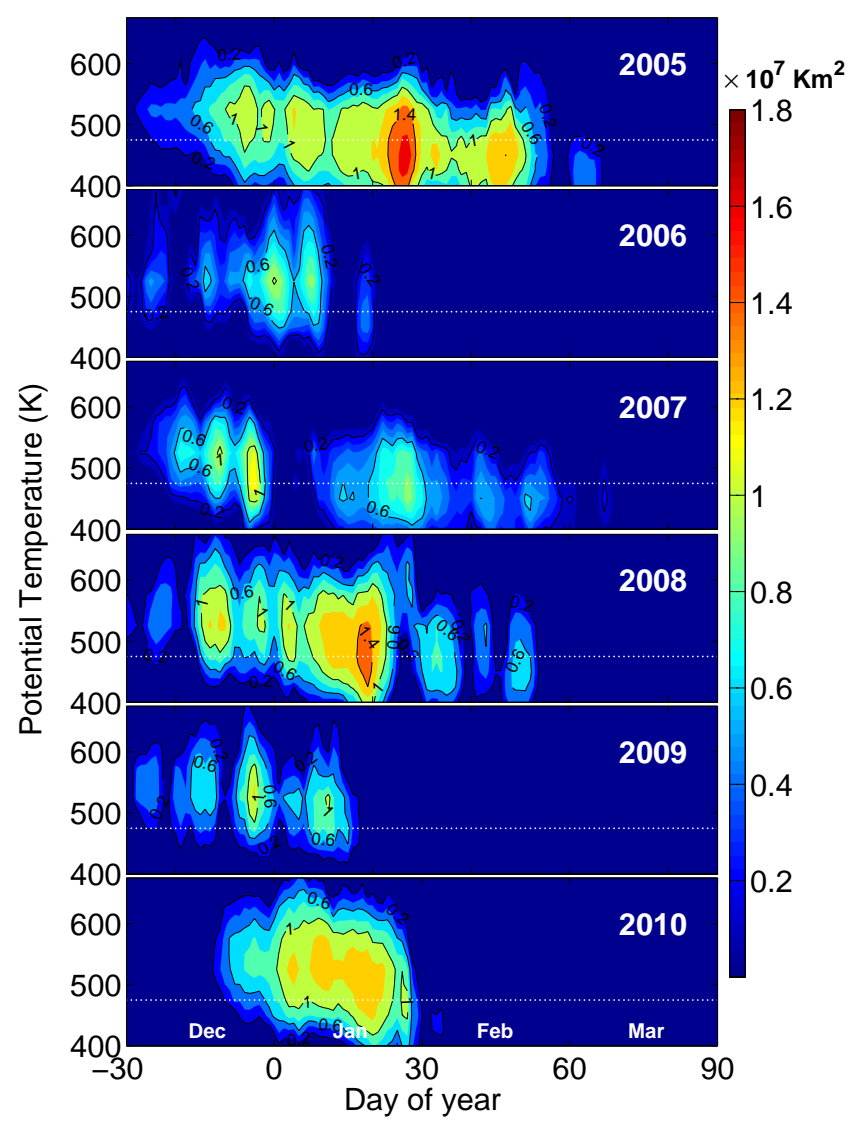

Fig. 1. The area $\left(\mathrm{km}^{2}\right)$ covered by PSCs (between 400 and $675 \mathrm{~K}$ ) inferred from the ECMWF temperature data for the Arctic winters 2005-2010. PSCs are assumed to form at the NAT frost point. The dotted line represents the $475 \mathrm{~K}$ and the topmost boundary stands for $675 \mathrm{~K}$ potential temperature level.

on water-ice particles. The composition of liquid aerosols is calculated analytically (Luo et al., 1995). The ice particles are assumed to incorporate $\mathrm{HNO}_{3}$ in the form of NAT described by a bimodal size distribution (Davies et al., 2002). $\mathrm{Cl}_{\mathrm{y}}$ and $\mathrm{Br}_{\mathrm{y}}$ are explicitly calculated from their long-lived sources at the surface and are therefore time dependent. An additional 6 pptv of bromine in the form of $\mathrm{CH}_{2} \mathrm{Br}_{2}$ is added to $\mathrm{Br}_{\mathrm{y}}$ to represent the contribution of brominated short lived species reaching the stratosphere (WMO, 2007).

For each Arctic winter considered here, the model was run from 1 December to 31 March. Initialisation of ozone on 1 December was provided by the ECMWF operational analyses. Other species in Mimosa-Chim were initialised from a long-term simulation of the REPROBUS CTM driven by ECMWF meteorological analyses. 


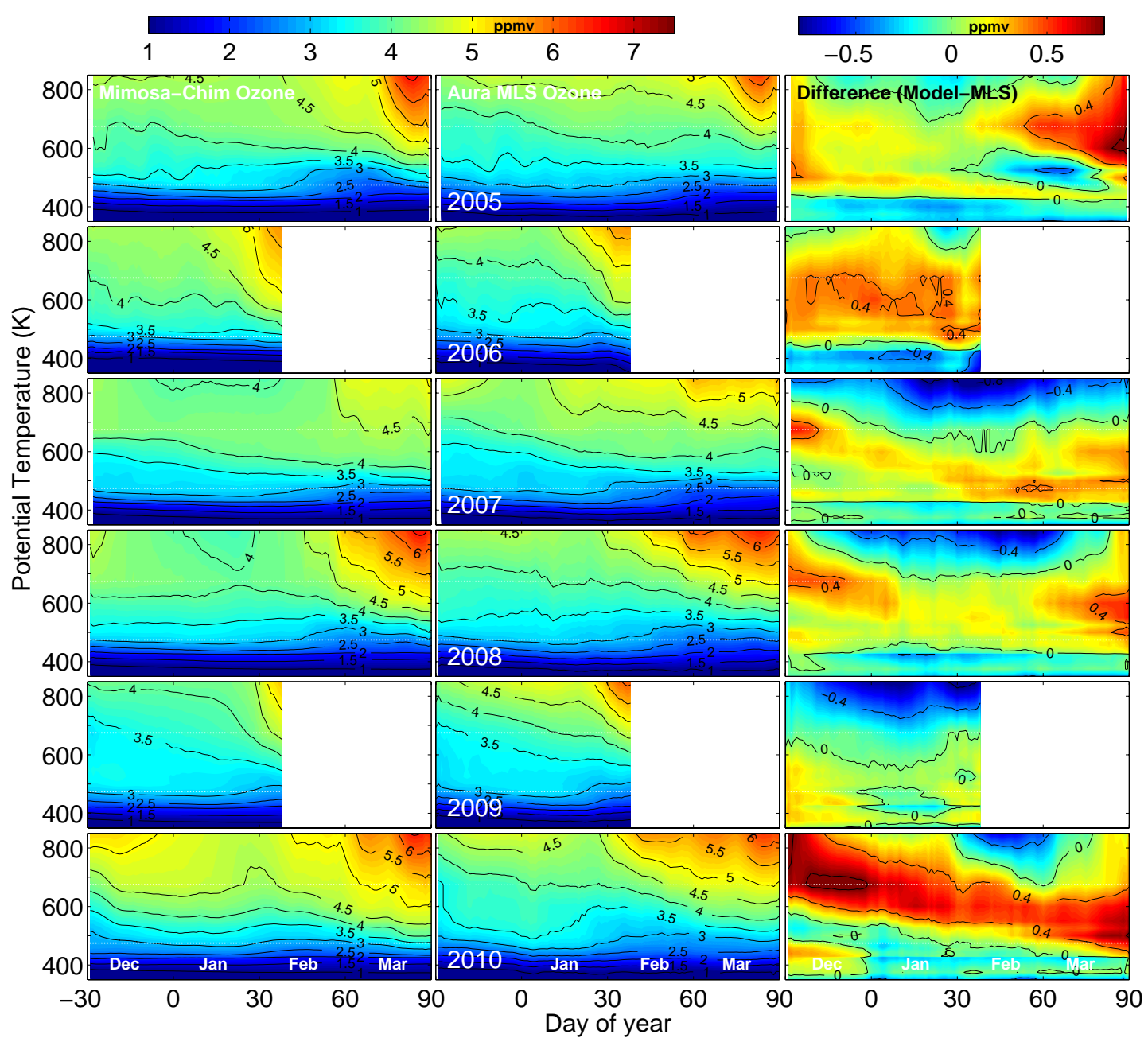

Fig. 2. Temporal evolution of the vertical distribution $(350-850 \mathrm{~K})$ of vortex averaged $\left(\geq 65^{\circ} \mathrm{EqL}\right)$ ozone (ppmv) for the Arctic winters 2005-2010. Left: Mimosa-Chim calculations, Middle: MLS measurements, and Right: The difference between modelled and measured ozone. The model fields are sampled at location of the MLS observations. Due to early vortex dissipation caused by major warmings, the analysis does not extend beyond 10 February in 2006 and 2009. Both data are smoothed for seven days. The white dotted lines represent the study altitudes 475 and $675 \mathrm{~K}$.

\section{Measurements: Aura MLS}

Ozone and $\mathrm{ClO}$ observations (version 2.2) from the Microwave Limb Sounder (MLS) aboard Aura are used to compare with the simulations. The retrieved ozone profiles have a vertical range of $215-0.02 \mathrm{hPa}$ and a vertical resolution of $\sim 3 \mathrm{~km}$, while the horizontal resolution of a profile is $\sim 200 \mathrm{~km}$. The vertical range of $\mathrm{ClO}$ is $100-0.1 \mathrm{hPa}$ and the vertical resolution is $3-3.5 \mathrm{~km}$, whereas the horizontal resolution ranges from 350 to $500 \mathrm{~km}$. The estimated accuracy is 5-10\% for ozone and $10-20 \%$ for $\mathrm{ClO}$ depending on altitude (Froidevaux et al., 2006; Santee et al., 2008).

\section{Temperature and PSCs during the winters}

Figure 1 shows the area covered by PSCs (Apsc) calculated from the ECMWF temperature and pressure data for the last six winters. PSCs are assumed here to form at the NAT frost point according to Hanson and Mauersberger (1988) and are calculated using climatological values of $\mathrm{HNO}_{3}$ and $\mathrm{H}_{2} \mathrm{O}$ (e.g. Tripathi et al., 2007). Winter 2005 shows the largest PSC area with a maximum of $1.7 \times 10^{7} \mathrm{~km}^{2}$ in late-January. Considerable area of PSC is also found in December-January 2008, with a maximum value of $1.4 \times 10^{7} \mathrm{~km}^{2}$ in mid-January. Due to a vortex split occurrence in mid-December at $475 \mathrm{~K}$ and a major warming in February 2010, Apsc during the winter is reduced and it shows a maximum of $1.2 \times 10^{7} \mathrm{~km}^{2}$ in mid-January. The 


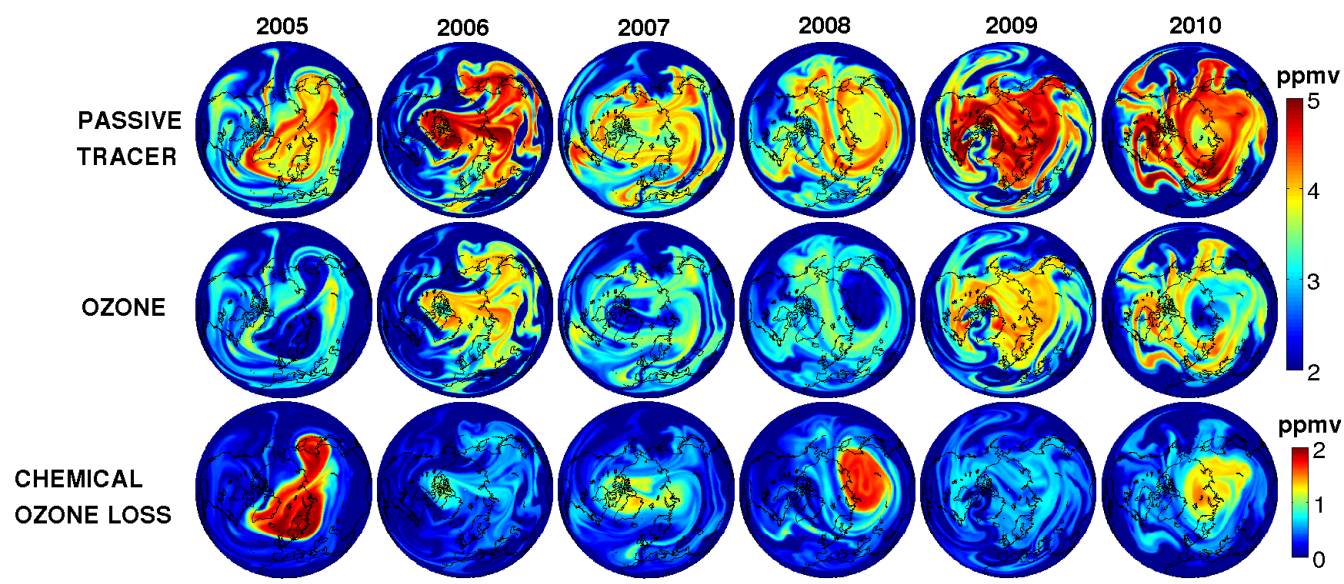

Fig. 3. Maps of passive tracer, ozone, and chemical ozone loss (passive tracer-ozone) calculated by Mimosa-Chim at $475 \mathrm{~K}$ on $15 \mathrm{March}$ 2005-2010.

warm winters 2006 and 2009 show much smaller PSC area, limited in late-December/early-January with a peak value of about $0.8 \times 10^{7} \mathrm{~km}^{2}$. In winter 2007 , the largest area of PSCs, $1.0 \times 10^{7} \mathrm{~km}^{2}$, is observed in late-December.

\section{Results}

We look into the details of ozone loss process of the recent winters in this section. Before starting the discussion on the loss, we first examine the ozone simulations. Since the passive method used for the loss diagnosis depends on tracer simulations, the quality of the model simulations has to be checked against measurements. Therefore, we compare the ozone calculations with MLS observations, as the instrument provides measurements of a number of compounds linked to polar ozone loss since its launch in 2004. It is followed by a discussion of the ozone loss estimated from the simulations. The temporal evolution of vortex averaged ozone loss in Mimosa-Chim and MLS are diagnosed afterwards. The ozone loss features are interpreted using modelled and measured chlorine activation in terms of $\mathrm{ClO}$ data. We later focus on the ozone loss analyses at two representative altitudes in the lower $(475 \mathrm{~K})$ and middle stratosphere $(675 \mathrm{~K})$.

\subsection{Ozone: simulation and comparison with MLS}

Figure 2 displays the vertical distribution of the MimosaChim and MLS ozone together with their difference, sampled at the same time and location of the satellite observations. The results are averaged inside the polar vortex defined as the area enclosed inside $65^{\circ} \mathrm{N}$ of equivalent latitude (EqL) (see Müller et al., 2008 for further discussions on adequate definition of polar vortex). Due to early final warming (since there was no strong or well-defined polar vortex, we take the major warming in late-January/early-February 2006 and 2009 as the final warming), the data beyond the events are not considered in this study.

Both simulations and measurements show similar maximum and exhibit a rather good agreement, with differences within \pm 0.5 ppmv depending on isentropic level and time. In general, the comparison yields good agreement in the lower stratosphere, below $500 \mathrm{~K}$ in particular. The calculations are in good agreement with the observations in the winters 2007, 2008 and 2009. The model captures well the ozone enhancement during the SSWs, specifically at higher altitudes, in January-February 2006 and 2009. The simulated middle stratospheric ozone levels during these periods are higher than those of other winters in accordance with the observations. In February 2010, the higher ozone values due to meridional transport of ozone rich air masses from lower latitudes, associated with a major SSW, can also be seen in both data sets. Inter-annual variability in the evolution of ozone with altitude is apparent in the figure. For instance, the winter 2005 shows low ozone values in the lower stratosphere up to $600 \mathrm{~K}$. Further, the ozone maximum in the winter 2007 is comparatively smaller than that of other winters. Nevertheless, as displayed in the right panel of Fig. 2, the simulations systematically overestimate (up to $0.7 \mathrm{ppmv}$ ) the observations in early-December and March above $600 \mathrm{~K}$ in all winters, due to differences in subsidence. This difference is found to be largest in March 2005, and in December and March 2010. In 2006, the model shows higher values of around 0.25 ppmv from December to February at 500 $800 \mathrm{~K}$. On the other hand, the calculations underestimate (up to $0.5 \mathrm{ppmv}$ ) the measurements in January-February below $450 \mathrm{~K}$ and above $675 \mathrm{~K}$ in most winters. Among the winters the smallest differences are found in 2008 and the largest differences in 2010. 


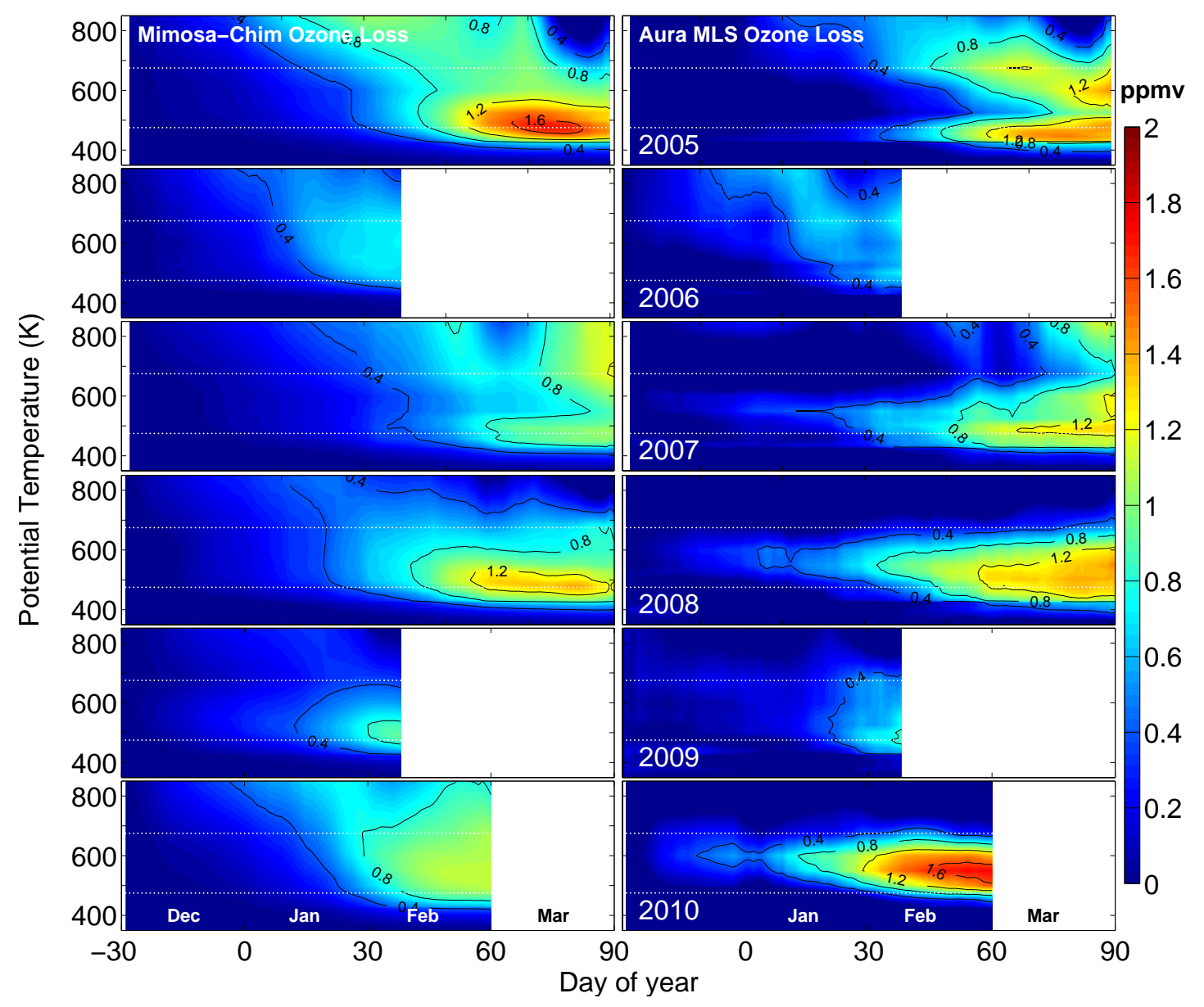

Fig. 4. Temporal evolution of the vertical distribution $(350-850 \mathrm{~K})$ of vortex averaged $\left(\geq 65^{\circ}\right.$ EqL) ozone loss (ppmv) estimated for the Arctic winters 2005-2010. Left: the ozone loss derived from the difference between the passive tracer and the chemically integrated ozone by Mimosa-Chim. Right: the ozone loss derived from the difference between the Mimosa-Chim passive tracer and the ozone measured by MLS. The model fields are sampled at location of the MLS observations. Due to early vortex dissipation caused by the major warmings, the analysis does not extend beyond 10 February in 2006 and 2009. The ozone loss analysis in March 2010 are not included here because of very weak vortex and due to the tracer uncertainties after the major warming. Both data are smoothed for seven days. The white dotted lines represent the study altitudes 475 and $675 \mathrm{~K}$.

\subsection{Ozone loss}

\subsubsection{Simulations}

The ozone chemical loss is computed from the difference between a passive tracer initialised identically to ozone at the beginning of the simulation and the chemically integrated ozone (i.e., Ozone loss=Tracer-Ozone). As an example, Fig. 3 shows the passive tracer, ozone, and the difference (chemical ozone loss) calculated at $475 \mathrm{~K}$ on 15 March for each winter. In the figure, polar vortices with high ozone mixing ratios of around $4.5 \mathrm{ppmv}$ corresponding to warm winters and reduced mixing ratios of around $3 \mathrm{ppmv}$ corresponding to cold winters, are clearly shown.

Since the winter 2005 was one of the coldest, a vast vortex and large reduction in ozone is simulated, suggesting sus- tained and high ozone depletion during the winter. Though not as large as observed in 2005, a significant area of low ozone levels off the pole is visible in 2008. Due to a strong SSW around mid-January, there was no vortex afterwards and hence high ozone is simulated in 2006 and 2009. In 2007 , the vortex was seemingly smaller and therefore the ozone depletion is reduced. In 2010, even though there was a major SSW in late-January due to a planetary wave 1 event, the vortex split and merged again later. Therefore, a small dissipated vortex, displaced into the mid-latitude, with moderate ozone loss is simulated in that period. The maps displayed in Fig. 3 clearly illustrate the strong inter-annual variability in the meteorology and chemical ozone loss in the Arctic, with large losses ( 2 ppmv) diagnosed inside the polar vortex in 2005 and 2008, more limited loss in 2007 and 2010 


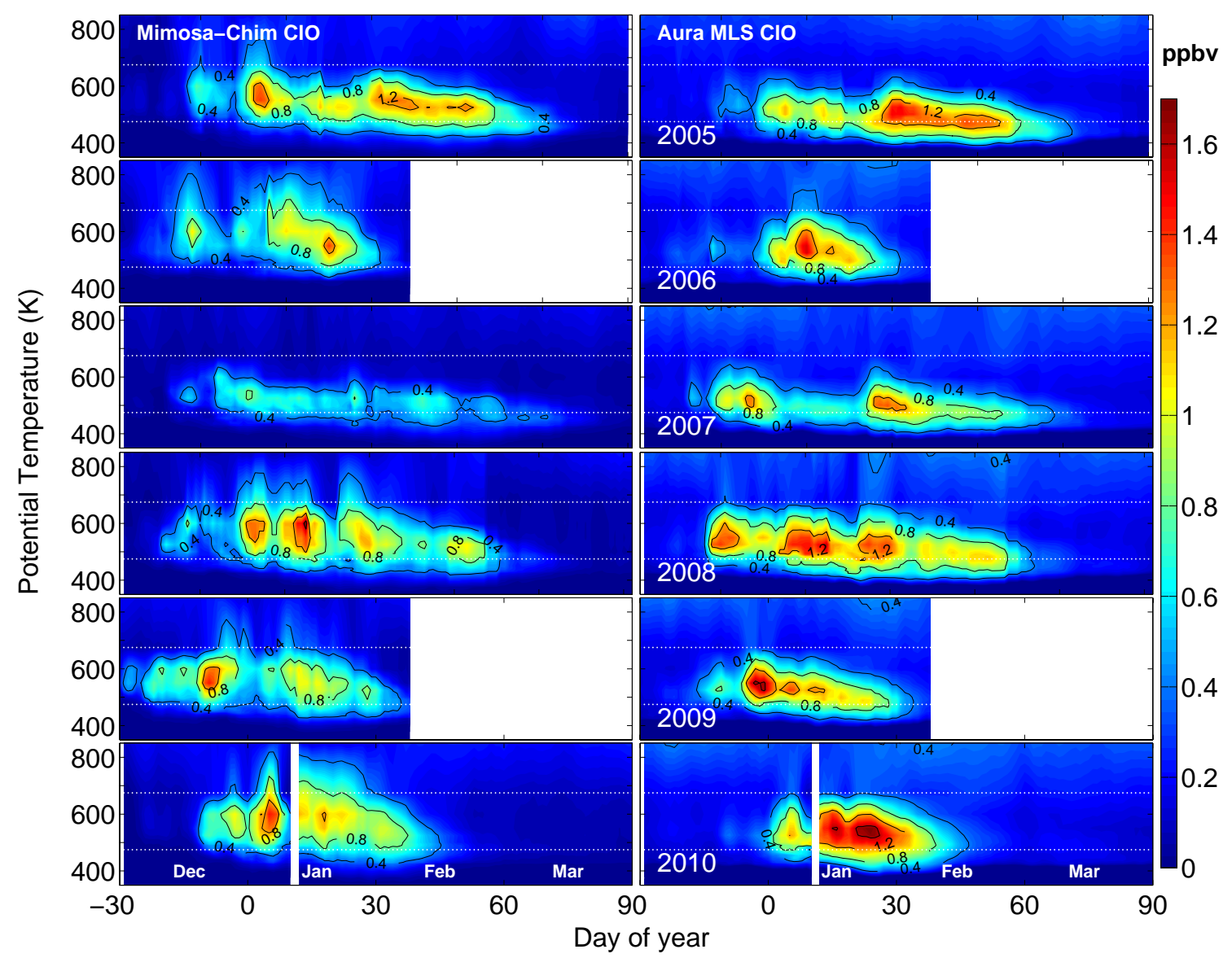

Fig. 5. Temporal evolution of the vertical distribution $(350-850 \mathrm{~K})$ of vortex averaged $\left(\geq 65^{\circ} \mathrm{EqL}\right) \mathrm{ClO}$ (ppbv) for the Arctic winters $2005-$ 2010. Left: Mimosa-Chim calculations and Right: MLS measurements. The Model and MLS ClO coincident profiles are selected for solar zenith angles $<89^{\circ}$ and local time between $10 \mathrm{~h}$ and $16 \mathrm{~h}$. Both data are smoothed for three days. MLS ClO values are corrected for the negative bias identified by Santee et al. (2008).

(0.8-1 ppmv), and the absence of vortex, as of 15 March, in 2006 and 2009. Thus, as discussed in Sect. 1, the most recent Arctic winters show a wide variety of polar processing, quite in line with previous northern winters.

\subsubsection{Comparison with MLS: vertical features}

Figure 4 (left panel) displays the vertical structure of the accumulated chemical ozone loss computed from the simulations for the winters 2005-2010. The vortex averaged ozone loss computed from the model grids and at the MLS sampling points show rather small differences. Therefore, we present the ozone loss computed at the MLS footprints inside the vortex for each winter for comparison purpose.

Among the winters, 2005 exhibits the largest ozone loss with a maximum of $1.7 \mathrm{ppmv}$ in March around $475 \mathrm{~K}$. The loss is spread vertically between 450 and $850 \mathrm{~K}$ in JanuaryFebruary, reaching 1.5 ppmv above $600 \mathrm{~K}$ in late-February. In March, most of the loss is confined between 400 and
$600 \mathrm{~K}$. Comparatively large losses are also found in the cold winters 2007 and 2008. In 2007, the ozone loss shows a double peak feature with a maximum of $1.3 \mathrm{ppmv}$ at $675 \mathrm{~K}$. In 2008, the ozone loss is delimited between 450 and $600 \mathrm{~K}$ with a peak loss of 1.4 ppmv around $475 \mathrm{~K}$. Little loss is computed above the $650 \mathrm{~K}$ level in this winter. Due to major warmings, the winters 2006 and 2009 show limited ozone loss, not exceeding 0.8 ppmv. The winter 2009 presents the smallest vertical extent in the diagnosed ozone loss, which is mainly centred below $650 \mathrm{~K}$ until the final warming. In 2010 , a wide spread loss of around 0.9 ppmv from mid-January to February at $450-800 \mathrm{~K}$ with a peak loss of about $1.1 \mathrm{ppmv}$ at $600 \mathrm{~K}$ is estimated. Ozone loss analysis for this winter is restricted until February due to problems in tracer descent after the warming, as identified from the modelled $\mathrm{N}_{2} \mathrm{O}$ isopleths. Additionally, there was no activated chlorine to induce a sustained loss afterwards in March. Study by Goutail et al. (2010) also show that the ozone loss has stopped by the end of February. 
Figure 4 (right panel) describes the temporal evolution of the vertical distribution of vortex averaged ozone loss derived from the observations. Ozone loss from the measurements is computed in a similar way as for the simulation (the difference between the passive ozone tracer sampled at each measurement point and observed ozone). In agreement with the calculations, comparatively large losses are estimated from the measurements in 2005 and 2008, reaching 1.5 and 1.4 ppmv respectively. The simulations reproduce quite well the gross features of observed ozone loss in each winter, e.g. its onset in the course of the winter, the altitude of its maximum and its vertical distribution. The agreement between the model and MLS is particularly good in 2006, 2007, 2008 and 2009 , where the differences are mostly within $\pm 0.2 \mathrm{ppmv}$. As shown in Fig. 2, the modelled ozone in March is comparatively higher and therefore, the maximum ozone loss is slightly lower in the model depending on altitude. In 2010, the computed loss from MLS is about 0.5 ppmv larger than that of Mimosa-Chim. This difference is due to relatively higher values $(0.5-0.8 \mathrm{ppmv})$ in simulated ozone throughout the winter at $500-700 \mathrm{~K}$ and also because of larger passive tracer values calculated after the warming, as compared to previous winters. However, in 2005 the model does simulate the second ozone loss maximum observed around $600 \mathrm{~K}$, albeit with a lesser amplitude. In both cases, the results show a large ozone loss in the middle stratosphere, as compared to other winters followed by its strong decrease in March. In addition, both the simulations and observations provide the highest ozone loss above $500 \mathrm{~K}$ in 2007 . To further investigate the causes of differences in the estimated ozone loss, we analyse the measured chlorine activation and its representation in the model in the next section.

\subsubsection{Comparison: $\mathrm{ClO}$ and Chlorine activation}

Figure 5 compares the temporal evolution of vertical distribution of vortex averaged $\mathrm{ClO}$ extracted from MLS observations and Mimosa-Chim simulations for various winters. As expected from large areas of PSCs, the observations show high chlorine activation in 2005, 2008, and 2010 with enhanced $\mathrm{ClO}$ values in the lower stratosphere up to about $600 \mathrm{~K}$. In these winters, vortex averaged $\mathrm{ClO}$ reach $1.2-1.5 \mathrm{ppbv}$ around $550 \mathrm{~K}$ in January. Chlorine activation usually starts in December above $475 \mathrm{~K}$ (in late-December during the first two winters and a little earlier in the later ones) and then extends lower down in the course of the winter. Both simulated and measured $\mathrm{ClO}$ occupy a larger vertical stretch and exhibit higher values in January 2010 as compared to other winters, consistent with higher ozone loss estimated in that period. The simulations generally reproduce the observed $\mathrm{ClO}$ and its variability throughout the winter quite well, although some differences are seen. In 2005 and 2010, a stronger chlorine activation extending up to $650 \mathrm{~K}$ is simulated in late-December as compared to the observations. In 2005, later during the winter, higher $\mathrm{ClO}$ values are observed in MLS extending up to mid-March. This discrepancy explains the stronger ozone loss derived from the observations at 500-600 K in March (see Fig. 4). In 2007, Mimosa-Chim clearly underestimates the observed chlorine activation. The vortex averaged $\mathrm{ClO}$ in Mimosa-Chim is lower by about $0.4 \mathrm{ppbv}$, which explains the underestimation of ozone loss in the simulations for that year. In other winters, the simulations show generally a good agreement with the observations at most altitudes. A closer examination of the ozone loss in the lower and middle stratosphere at two representative isentropic levels, 475 and $675 \mathrm{~K}$, is presented in the following sections.

\subsubsection{Comparison: lower stratosphere}

As shown by Fig. 4, the simulated ozone loss until January is generally within 0.2 ppmv and it varies in January-March for each year at $475 \mathrm{~K}$. The maximum ozone loss derived from the simulations is, respectively, 1.7, 0.7, 1.1, 1.3, 0.9 and 0.9 ppmv in 2005, 2006, 2007, 2008, 2009 and 2010. The corresponding observed losses are in turn 1.5, 0.7, 1.2, 1.4, 0.8 and $0.9 \mathrm{ppmv}$, and are in very good agreement with the simulated ones, with differences within $\pm 0.2 \mathrm{ppmv}$.

The ozone loss obtained from our study is in general good agreement with that obtained from other techniques for the winter 2005 (WMO, 2007), 2006 (Manney et al., 2007) and 2007 (Rösevall et al., 2008). Table 1 presents the comparison of ozone loss derived from various measurements and model calculations for the winter 2005. The maximum loss simulated at $475 \mathrm{~K}$ is about $1.7 \mathrm{ppmv}$ ( $1.5 \mathrm{ppmv}$ from MLS) in 2005, which compares well with that of Grooß and Müller (2007). Our loss estimations are also in very good agreement with those of Jackson and Orsolini (2008); Rösevall et al. (2007); Singleton et al. (2007) and Tsvetkova et al. (2007), as we estimate comparable values in respective periods. It must be noted that the ozone loss computed from MLS observations by Manney et al. (2006) and Amraoui et al. (2008) also show the same maximum of $1.5 \mathrm{ppmv}$, which greatly support our ozone loss computation technique. However, the peak ozone loss altitude shown by some works are generally about $25 \mathrm{~K}$ lower than in our analysis. Such a discrepancy among various techniques was also noted by Grooß et al. (2005a) for the winter 2003. The only diagnosis that departs considerably from all other evaluation is Rösevall et al. (2007), with Submillimeter Radiometer (SMR) data. This could be due to the peculiarity of their method, which is prone to more mixing and dilution in the vortex air. The vertical motion was not represented explicitly but was calculated from $\mathrm{N}_{2} \mathrm{O}$ measurements for their analyses. Other details regarding the method can be found from Jackson and Orsolini (2008), who provide a brief comparison of most ozone loss estimation techniques. In agreement with the measured and simulated ozone loss and Apsc, the chlorine activation is predominant in 2005 and 2008, moderate in 2010, and weak in 2007 at $475 \mathrm{~K}$. The winters 2006 and 2009 started off with low temperatures 
Table 1. The vortex averaged ( $\geq 65^{\circ} \mathrm{EqL}$ ) ozone loss estimated in volume mixing ratio (ppmv) from Mimosa-Chim and MLS data, compared to different studies for the Arctic winter 2005. The initial offset in tracer and Mimosa-Chim ozone is corrected with respect to MLS ozone to avoid any bias in ozone loss computations. The passive tracer method is denoted by PT and the vortex averaged/profile descent method is denoted by VAO. The ozone loss analyses based on assimilated data are indicated by *

\begin{tabular}{lcccll}
\hline Study & Method & Loss/ppmv & Peak altitude & Period & Measurements \\
\hline This study & PT & 1.5 & $475 \mathrm{~K}$ & Dec/Mar & MLS \\
Manney et al. (2006) & VAO & 1.5 & $450 \mathrm{~K}$ & Jan/10 Mar & MLS \\
Amraoui et al. (2008) & VAO & 1.5 & $425 \mathrm{~K}$ & $10 \mathrm{Jan} / 10 \mathrm{Mar}$ & MLS \\
Singleton et al. (2007) & PT & 1.8 & $450 \mathrm{~K}$ & Jan/Mar & MLS \\
Jin et al. (2006) & Various & $1.8-2.3$ & $475-550 \mathrm{~K}$ & $1-7 \mathrm{Jan} / \mathrm{mid}-\mathrm{Mar}$ & ACE/FTS \\
Rex et al. (2006) & Match & $1.3-2.1$ & $450-475 \mathrm{~K}$ & $\mathrm{Jan} / 25 \mathrm{Mar}$ & Ozonesondes \\
Tsvetkova et al. (2007) & VAO & 1.7 & $450 \mathrm{~K}$ & $\mathrm{Jan} / 25 \mathrm{Mar}$ & SAGE III \\
Rösevall et al. (2007) & VAO & 1.3 & $450 \mathrm{~K}$ & $\mathrm{Jan} / 14 \mathrm{Mar}$ & MLS* \\
Jackson and Orsolini (2008) & VAO & 1.2 & $450 \mathrm{~K}$ & early-Jan/early-Mar & MLS/SBUV2* \\
Rösevall et al. (2007) & VAO & $0.6-0.9$ & $450 \mathrm{~K}$ & Jan/14 Mar & SMR/Odin* \\
\hline & & & & & Simulation \\
\hline This study & PT & 1.7 & $475 \mathrm{~K}$ & Dec/Mar & Mimosa-Chim \\
Grooß and Müller (2007) & PT & $1.4 \pm 0.3$ & $475 \mathrm{~K}$ & Jan/Mar & CLAMS \\
Singleton et al. (2007) & PT & $2.4 / 2.3$ & $450 / 475 \mathrm{~K}$ & Jan/Mar & SLIMCAT \\
\hline
\end{tabular}

and therefore, were subjected to early chlorine activation and ozone loss as compared to other winters. It has to be recalled that a similar range of ozone loss values, from 0.7 to 2.3 ppmv, was also computed for the cold Arctic winter 2000 by various methods (Newman et al., 2002).

\subsubsection{Comparison: middle stratosphere}

As evident in Fig. 4, the simulated ozone loss at $675 \mathrm{~K}$ is around $0.2 \mathrm{ppmv}$ in early-January in most winters. The maximum loss reaches $1.1,0.7,1.2,0.8,0.3$, and $0.9 \mathrm{ppmv}$ in 2005, 2006, 2007, 2008, 2009, and 2010, respectively. The loss derived from observations show successively $1.2,0.6$, $0.8,0.7,0.5$, and $0.7 \mathrm{ppmv}$ for the corresponding winters. The simulated ozone depletion shows good agreement with that of observations, within $\pm 0.2 \mathrm{ppmv}$. The large loss calculated around $675 \mathrm{~K}$ in January-February 2005 is also confirmed by other estimations (Jin et al., 2006; Rex et al., 2006; Grooß and Müller, 2007; Tsvetkova et al., 2007; Jackson and Orsolini, 2008). The high ozone depletion simulated at $675 \mathrm{~K}$ is in good agreement with that of Grooß and Müller (2007), who estimate a similar loss at this altitude. This double peak structure is not pronounced in the analysis of Singleton et al. (2007) and thus, the measured and simulated ozone loss in their study are considerably smaller (about $0.7 \mathrm{ppmv}$ ) than our estimates. There is only a little amount of active chlorine present at $675 \mathrm{~K}$, as most of it is found below $600 \mathrm{~K}$. Therefore, key factors driving ozone loss at $675 \mathrm{~K}$ will be discussed in the succeeding sections.

\section{Discussion}

\subsection{Ozone loss and production rates}

To gain further insights into the inter-annual variability of ozone in the Arctic vortex, we have calculated the ozone loss and production rates for the winters 2005-2010. The following equation was applied to compute the vortex averaged ozone loss and production rates from the model output.

$$
\overline{\delta \mathrm{O}_{3}(\theta, j)} \quad(\mathrm{ppbv} / \mathrm{sh})=\frac{\sum_{\lambda_{\text {eq }}=65}^{\lambda_{\text {eq }}=90} \delta \mathrm{O}_{3}\left(\theta, j, \lambda_{\text {eq }}\right) \times \operatorname{sh}\left(\theta, j, \lambda_{\text {eq }}\right)}{\sum_{\lambda_{\text {eq }}=65}^{\lambda_{\text {eq }}=90} \operatorname{sh}\left(\theta, j, \lambda_{\text {eq }}\right)}
$$

where, $\overline{\delta \mathrm{O}_{3}(\theta, j)}$ is the ozone loss or production averaged within $\operatorname{EqL}\left(\lambda_{\text {eq }}\right) \geq 65^{\circ}$ for each model isentrope $(\theta)$ and day $(j) . \delta \mathrm{O}_{3}\left(\theta, j, \lambda_{\text {eq }}\right)$ is the instantaneous ozone loss or production calculated by the model for each grid point defined by latitude $(\phi)$ and longitude $(\psi)$ for each $\theta$ and $j . \operatorname{sh}\left(\theta, j, \lambda_{\text {eq }}\right)$ is the sunlit hour calculated with respect to solar zenith angle $<95^{\circ}$ that varies between 0 and 1 for complete darkness to full illumination. The $\lambda_{\text {eq }}$ is computed for each model grid $(\theta, \phi, \psi)$ and for each day using potential vorticity (PV) data.

Figure 6 shows the vortex averaged instantaneous ozone loss and production rates in ppbv per sunlit hour (ppbv/sh) at 475 (top panel) and $675 \mathrm{~K}$ (bottom panel). 


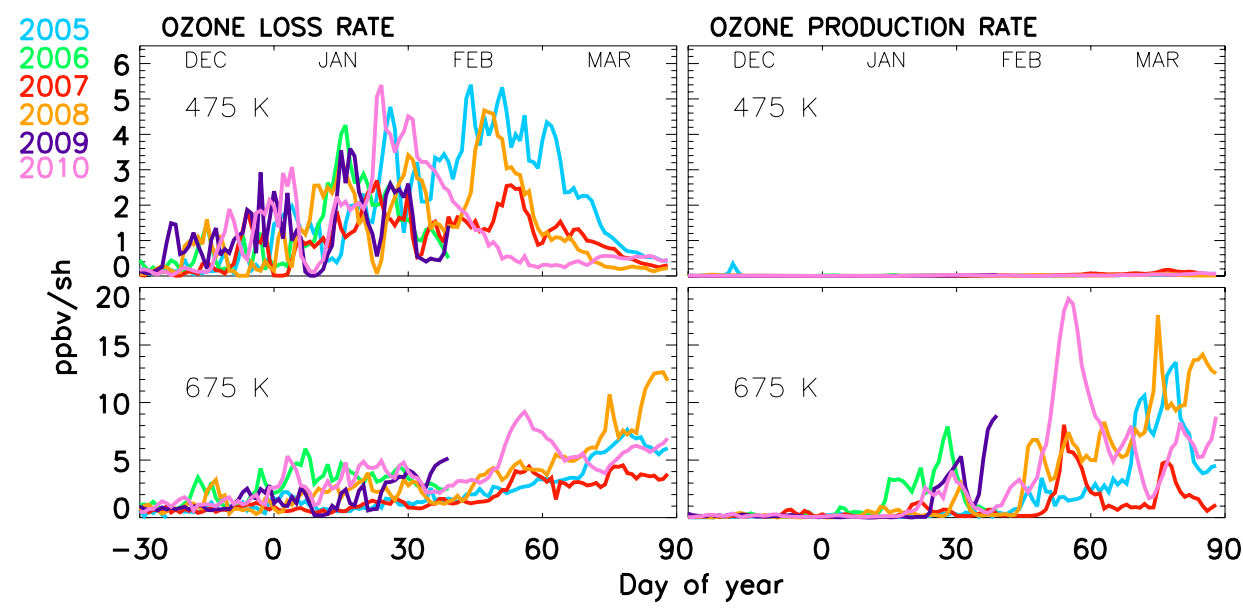

Fig. 6. Vortex averaged ( $\geq 65^{\circ} \mathrm{EqL}$ ) chemical ozone loss and production rates at 475 and $675 \mathrm{~K}$, expressed in ppbv per sunlit hour (ppbv/sh), for the Arctic winters 2005-2010. The data are exempted from temporal smoothing to explicitly show the effect of daily movement of vortex and its impact on ozone production and loss rates.

\subsubsection{Lower stratosphere}

At $475 \mathrm{~K}$, the winter 2005 shows the largest loss rate of around $5 \mathrm{ppbv} / \mathrm{sh}$ in February. In 2010, loss rates of 3$5 \mathrm{ppbv} / \mathrm{sh}$ are calculated in mid-January/mid-February, while relatively lower depletion rates are found in 2008 and 2007 during these months. The warm winters 2009 and 2006 show loss rates up to 3-4 ppbv/sh in December and mid-January respectively, which are higher than those of the cold winters during the same period. There is hardly any ozone production at this isentropic level.

For the winters discussed here, there are no other studies with which to compare our simulated ozone loss rates. Therefore, we compare the results of previous Arctic winters from Frieler et al. (2006). They derive ozone loss rates (seven/ten day averages) of $5-10 \mathrm{ppbv} / \mathrm{sh}$ at $490 \mathrm{~K}$ in 1995 , $5-8 \mathrm{ppbv} / \mathrm{sh}$ at $475 \mathrm{~K}$ in $1996,6-7 \mathrm{ppbv} / \mathrm{sh}$ at $500 \mathrm{~K}$ in 2000 , $4.5-8.5 \mathrm{ppbv} / \mathrm{sh}$ at $475 \mathrm{~K}$ in 2001 and $4-5 \mathrm{ppbv} / \mathrm{sh}$ at $475 \mathrm{~K}$ in 2003 in January. Since calculation of Frieler et al. (2006) is based on a box model, the figures are not directly comparable. However, our results are generally in good agreement with their analyses. For instance, (i) both observations and our simulations show higher loss rates in late-January/earlyFebruary, (ii) the loss rates in warm winters rarely extend beyond January, but are higher than those for most cold winters for the same period, and (iii) cold winters with sustained loss show higher simulated loss rates in January/mid-March, consistent with the measured rates.

\subsubsection{Middle stratosphere}

At $675 \mathrm{~K}$, ozone loss and production rates tend to increase with time until February. The largest loss rates of our study are found in February-March 2008, around $12 \mathrm{ppbv} / \mathrm{sh}$. In
2010, elevated loss rates of 4-9 ppbv/sh are simulated in midFebruary/mid-March. A similar evolution of production rates is also calculated during these two winters, in which the latter shows a massive production of 5-19 ppbv/sh. The large loss of 2-6 ppbv/sh is masked by enhanced production of $2-14 \mathrm{ppbv} / \mathrm{sh}$ in mid-March 2005 . The loss rates dominate over production rates in 2007 except in late-February, which is consistent with the highest ozone loss found at $675 \mathrm{~K}$ in March. The warm winter 2006 records the largest loss and production rates in December-January in line with the high chlorine activation and ozone loss during the period.

Figure 7 shows the PV maps on 15 March of each year at $675 \mathrm{~K}$. Since ozone production depends solely on sunlight, the movement of vortex over illuminated regions causes its variation. As can be seen from the figure, the displacement of the vortex to the mid-latitudes explains the reasons for higher production rates in 2005, 2008 and 2010 as compared to other winters. This is also clearly seen in late-January/earlyFebruary in 2006 and 2009, and late-February/early-March 2010, during which the polar vortices were displaced off the pole by major SSW events (Manney et al., 2006; Flury et al., 2009; Kuttippurath et al., 2010). Further, it is evident from Fig. 6 that the production rate in March increases with time, which is well anticipated as the final warming approaches. On the other hand, a pole centred vortex and hence, comparatively diminished production rates are found in 2007 .

\subsection{Ozone loss and chemical cycles}

In order to better understand the prime chemical cycles driving the ozone loss inside the vortex in the lower and middle stratosphere, we have evaluated contribution of various chemical cycles as a function of time at 475 and $675 \mathrm{~K}$ for the winters discussed here. Contribution of each cycle is given in 


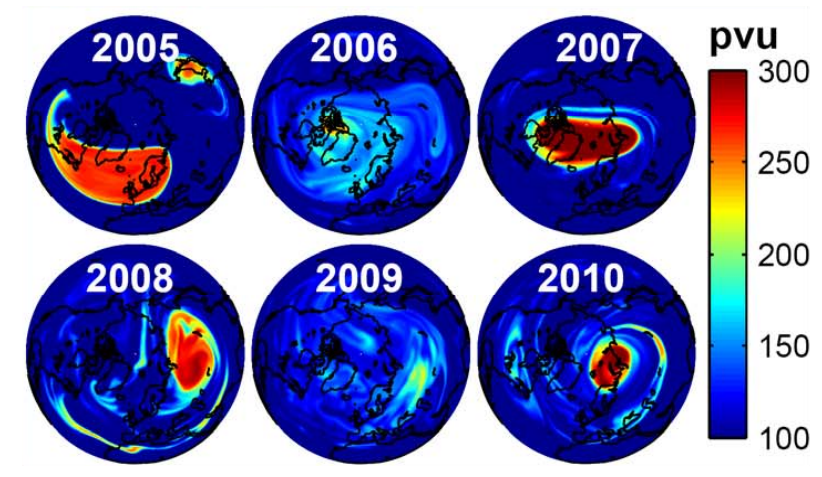

Fig. 7. Maps of potential vorticity (1 PV units $(\mathrm{pvu})=10^{-6} \mathrm{~km}^{2} \mathrm{~kg}^{-1} \mathrm{~s}^{-1}$ ) calculated from ECMWF data on 15 March $2005-2010$ at $675 \mathrm{~K}$. The maps also display the strength and position of polar vortex on 15 March in each winter.

percent of the total contribution from all cycles. This contribution is shown in Fig. 8 left panel for the lower stratosphere $(475 \mathrm{~K})$ and right panel for the middle stratosphere $(675 \mathrm{~K})$.

\subsubsection{Lower stratosphere}

The importance of halogen cycles in ozone destroying process in the polar lower stratosphere is relatively well known (e.g. WMO, 2007) and this study too finds similar results. At $475 \mathrm{~K}$, the $\mathrm{ClO}-\mathrm{ClO}$ and $\mathrm{ClO}-\mathrm{BrO}$ cycles represent $80-90 \%$ of the total loss (e.g. Frieler et al., 2006; Woyke et al., 1999). The $\mathrm{ClO}-\mathrm{O}$ cycle contributes $10 \%$ to the loss throughout the winter at this level, consistent with a previous study at $465 \mathrm{~K}$ based on UARS MLS (Upper Atmosphere Research Satellite MLS) measurements in the Arctic and Antarctic winter of 1993 (MacKenzie et al., 1996). The ClO dimer cycle is prominent in January/mid-March (since the ozone loss before January is very small, the contribution before the period is not shown), with a maximum contribution of $\sim 50 \%$ in mid-January/mid-February. Because of its quadratic dependence on $\mathrm{ClO}$, the efficiency of the $\mathrm{ClO}-\mathrm{ClO}$ cycle to destroy ozone falls very rapidly when active chlorine returns to reservoir forms at the end of the winter. This is not the case for the contribution of $\mathrm{BrO}-\mathrm{ClO}$, which decreases not as rapidly in these conditions, and therefore becomes larger than that of the $\mathrm{ClO}-\mathrm{ClO}$ cycle in early-March. When the $\mathrm{ClO}$ dimer cycle becomes less important, the contribution from $\mathrm{ClO}-\mathrm{BrO}$ enhances. A similar result was also observed by Butz et al. (2007) in the Arctic winter 1999 from balloon-borne measurements. From early-March onwards, as there are no PSCs and chlorine activation the contribution of the $\mathrm{HO}_{\mathrm{x}}$ and $\mathrm{NO}_{\mathrm{x}}$ cycles grow quickly and become the active ozone depleting cycles in the second half of the month.

Another interesting feature to note is the contribution of the cycles in 2010. During this winter temperatures were relatively high and as emphasised previously, the vortex was subjected to a major SSW and subsequent split. Therefore, in early-February the $\mathrm{ClO}-\mathrm{ClO}$ contribution fell dramatically and contribution from other cycles $\left(\mathrm{HO}_{\mathrm{x}}\right.$ and $\mathrm{BrO}-\mathrm{ClO}$ cycles in particular) dominated later during the winter for the reasons stated above. Contribution from $\mathrm{HO}_{\mathrm{x}}$ dominates during warming periods, and is demonstrated by its relatively higher contribution in the vortex dissipation (mid/lateMarch) or major SSW periods (late-January 2006 and 2009, and mid-February 2010). Since increase in mixing ratios of $\mathrm{H}_{2} \mathrm{O}$ and $\mathrm{HNO}_{3}$ during warmings are expected (e.g. Flury et al., 2009) and are the sources of $\mathrm{HO}_{\mathrm{x}}$, contribution from this cycle outweighs others (e.g. Marchand et al., 2005).

The maximum contribution of the $\mathrm{ClO}-\mathrm{ClO}$ cycle to the total loss varies from $\sim 50 \%$ in cold winters to $\sim 40 \%$ in warm winters. In contrast, contribution from $\mathrm{ClO}-\mathrm{BrO}$ equals that of $\mathrm{ClO}-\mathrm{ClO}$ in warm winters and decreases to $\sim 25-30 \%$ in cold winters. The larger difference in the contribution of both cycles, during the period of sustained ozone loss, is found in the winter 2008 from January to lateFebruary.

Our results on the contribution of halogens to the total loss are consistent with those found in Frieler et al. (2006). Using a photochemical box model, they also show a contribution of $50 \%$ from the $\mathrm{ClO}$ dimer, $\sim 27-48 \%$ from $\mathrm{BrO}-\mathrm{ClO}$ and 5$10 \%$ from $\mathrm{ClO}-\mathrm{O}$ to the total loss in the Arctic winters 1995, 1996, 2000, and 2001, and in the Antarctic winter 2003 in the lower stratosphere. They also find that the efficiency of the $\mathrm{BrO}-\mathrm{ClO}$ cycle increases with faster photolysis rate of $\mathrm{ClO}$ dimer. Studies using UARS MLS measurements for the Antarctic winters 1992-1994 also point out that these two cycles account nearly for $90 \%$ of the total loss in the lower stratosphere (Wu and Dessler, 2001). Therefore, our study confirms the fact that the odd oxygen loss in the polar winter lower stratosphere is dominated by the $\mathrm{ClO}$ dimer and $\mathrm{ClO}$ $\mathrm{BrO}$ catalytic cycles, which is quite in line with our current theoretical understanding and is consistent with the findings of previous studies.

\subsubsection{Middle stratosphere}

In contrast to what is found at $475 \mathrm{~K}$, the halogen catalysed cycles play comparatively a small role in the Arctic ozone depletion at $675 \mathrm{~K}$, as demonstrated in Fig. 8 (right panel). At this level, the ozone loss is essentially due to the NO$\mathrm{NO}_{2}$ cycle, which represents $50-75 \%$ of the total depletion in February-March, complemented by the $\mathrm{ClO}-\mathrm{O}$ cycle that contributes about 10-20\% to the total loss during the period. The ClO-O contribution is found to be as large as $20-55 \%$ in January. However, ozone loss at this altitude during the period is very small $(0-0.3 \mathrm{ppmv})$. The contribution of $\mathrm{HO}_{\mathrm{x}}$ cycle, which is about $10-20 \%$ in January, increases during the course of the winter to become equal or larger than that of $\mathrm{ClO}-\mathrm{O}$ in late winter. The rate limiting step in all these cycles is the combination of the oxygen atom with a specific molecule (for e.g. $\mathrm{HO}_{2}+\mathrm{O}$ for $\mathrm{HO}_{\mathrm{x}}$, and $\mathrm{ClO}+\mathrm{O}$ for $\mathrm{ClO}_{\mathrm{x}}$ ). 


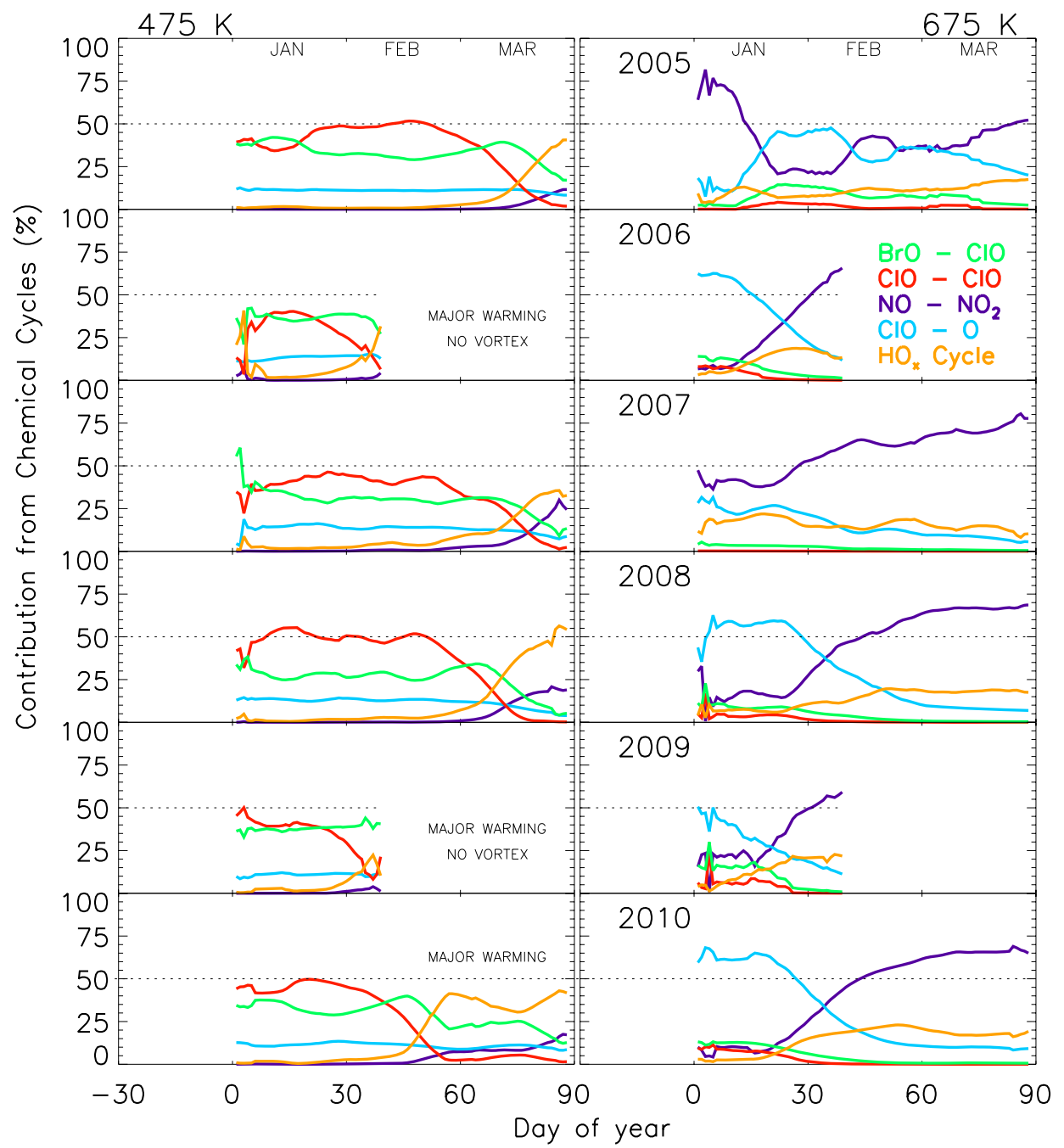

Fig. 8. Vortex averaged $\left(\geq 65^{\circ} \mathrm{EqL}\right)$ relative contribution of selected ozone depleting chemical cycles to the total chemical ozone loss at 475 (left panel) and $675 \mathrm{~K}$ (right panel) in the Arctic winters 2005-2010. The data are smoothed for ten-days. The dotted lines represent 50\% and the top lines of each plot represent $100 \%$ contribution.

Therefore, the availability of O-atoms mainly determines the efficiency and duration of these cycles and thus, the accumulated ozone loss at $675 \mathrm{~K}$.

The inter-annual variability is relatively strong for $\mathrm{ClO}-\mathrm{O}$ and $\mathrm{NO}-\mathrm{NO}_{2}$ cycles, markedly in January. The variability of $\mathrm{ClO}-\mathrm{O}$ contribution is linked to the formation of PSCs. The NO- $\mathrm{NO}_{2}$ cycle contributes 10-20\% in 2010, 2009, 2008 and 2006, but 30-45\% in 2005 and 2007 in January. The maximum ozone depletion simulated around $675 \mathrm{~K}$ in 2007 is in agreement with the relatively high contribution of $\mathrm{NO}-\mathrm{NO}_{2}$ during the winter. However, similar contribution of this cycle in other winters is compensated by large ozone production, as discussed in Sect. 6.1.

Unlike for lower stratosphere, only a few studies are performed on the aspects of contribution of different chemical cycles to the total loss above $650 \mathrm{~K}$. Moreover, the available studies on previous winters address contribution of the cycles in some specific issues such as ozone loss due to additional $\mathrm{NO}_{\mathrm{x}}$ loading during solar proton events or warming events (Grooß et al., 2005a; Vogel et al., 2008). For instance, box model calculations by Konopka et al. (2007) noted the efficiency of $\mathrm{NO}_{\mathrm{x}}, \mathrm{HO}_{\mathrm{x}}, \mathrm{ClO}-\mathrm{ClO}$ and $\mathrm{BrO}-\mathrm{ClO}$ cycles as $76,12.5,3.5$ and $1 \%$ respectively at $600-900 \mathrm{~K}$ during the warm Arctic winter 2003. Interestingly, large loss of ozone at higher altitudes with a double peak structure (as found in 2005) was simulated in this winter too (Grooß et al., 2005a). Simulated ozone loss for the winter is comparable to that of 2005 , with a maximum of around 1.4 ppmv at 475 and $675 \mathrm{~K}$. They also linked the higher loss above $600 \mathrm{~K}$ to the exposure of vortex air to sunlight that began early during this 
dynamically disturbed winter, in tune with their analyses for the southern winter 2002 (Grooß et al., 2005b). These results are in agreement with our analysis for the warm winters, during which the contribution from $\mathrm{NO}_{\mathrm{x}}$ is larger than that of the cold winters, inducing higher ozone loss above $600 \mathrm{~K}$. Therefore, in PSC-free polar stratosphere in $600-850 \mathrm{~K}$, the $\mathrm{NO}-\mathrm{NO}_{2}$ cycle plays a major role in ozone depletion.

\subsection{Partial column ozone loss}

To complement our ozone depletion analysis based on mixing ratio, we have computed the ozone column loss for each winter from both the Mimosa-Chim simulations and MLS observations. For the integration, the model ozone and tracer profiles were interpolated to the MLS sampling points inside the vortex $\left(\geq 65^{\circ} \mathrm{EqL}\right)$. The MLS profiles were then interpolated to the vertical levels of the model in order to have the same column computation procedure for both data sets. Most studies concentrate the ozone column loss in the lower stratosphere, and therefore we have calculated the loss in the 350$550 \mathrm{~K}$ column range. In order to analyse the contribution from middle stratosphere by cycles like $\mathrm{NO}_{\mathrm{x}}$, as discussed in the previous section, we have computed the column loss for the whole $350-850 \mathrm{~K}$ range. Except for the warm winters 2006, 2009 and 2010, the accumulated column loss are estimated from December through the end of March. Calculations for the warm winters are restricted to 10 February for 2006 and 2009, and 28 February for 2010, consistent with our previous analysis. The daily average ozone and tracer data are used for these column loss calculations. The resulting column losses in $350-550 \mathrm{~K}$ and $350-850 \mathrm{~K}$ for each winter are given in Table 2.

For the $350-850 \mathrm{~K}$ partial column, the largest loss is found in 2005 and the lowest loss in 2006, in agreement with our previous discussion on the vertical distribution of ozone loss. In 2005 and 2008, the column loss simulated by the model is respectively 109 and $98 \mathrm{DU}$ while that derived from the MLS observations amounts to respectively 112 and 115 DU. In the warm winters 2006 and 2009, a limited loss reaching 53 DU (in 2009) is simulated. The most recent warm winter 2010 is characterised by a moderate loss of 79 DU by the end of February. The column loss calculated by the model overestimates the measured loss in all three warm winters (2006, 2009 and 2010) by 16-19DU. These figures from Mimosa-Chim and MLS compare reasonably well with those derived from the ground-based total column observations from UV-visible SAOZ (Systeme d'Analyse par Observation Zenithale) network in the Arctic (Goutail et al., 2005, 2010). As shown by the simulations, large loss in cold and relatively small loss in warm winters are computed from the SAOZ measurements. The SAOZ estimations are generally in good agreement with those of Mimosa-Chim/MLS, with deviations within 20 DU. In 2010, the difference is much larger, reaching 40 and $60 \mathrm{DU}$ with the simulations and MLS observations respectively. The offset between SAOZ and Mimosa-
Table 2. The vortex averaged ( $\geq 65^{\circ} \mathrm{EqL}$ ) accumulated ozone partial column loss (DU) estimated in 350-850 and 350-550 K from the MLS sampling inside the vortex and corresponding MimosaChim simulations interpolated to the observed points for each winter (121 Days from December to March). The SAOZ total column loss computations for the winters are compared to Mimosa-Chim and MLS loss estimates in $350-850 \mathrm{~K}$. The calculations for the warm winters 2006 and 2009 are performed for 72 days (from 1 December to 10 February), and 2010 for 90 days (from 1 December to end of February). The maximum loss is found (shown below) around 23-25 March in cold winters. The initial offset between tracer and MLS/Mimosa-Chim ozone is corrected with respect to MLS ozone to account for any biases in ozone loss computations. The column loss is computed from the the daily average of ozone and tracer column found inside the vortex.

\begin{tabular}{lcccccc}
\hline $350-850 \mathrm{~K}$ & 2005 & 2006 & 2007 & 2008 & 2009 & 2010 \\
\hline Mimosa-Chim & 109 & 42 & 80 & 98 & 53 & 79 \\
MLS & 115 & 26 & 84 & 112 & 38 & 60 \\
SAOZ & 103 & 58 & 99 & 115 & 56 & 120 \\
\hline $350-550 \mathrm{~K}$ & & & & & & \\
\hline Mimosa-Chim & 91 & 27 & 57 & 80 & 43 & 55 \\
MLS & 81 & 14 & 62 & 90 & 28 & 42 \\
\hline
\end{tabular}

Chim/MLS ozone loss can be due to differences in the vortex limit criteria and sampling. That is, the ground-based estimations depend on seven stations in the vortex, while the MLS sampling covers relatively quite well the polar region. Additionally, the ground-based analysis uses slightly different vortex criterion and the column measurements do not sample vortex air at all altitudes, whereas only vortex air is considered in our analysis.

The ozone loss in the lower stratosphere, in $350-550 \mathrm{~K}$, shows similar features as noted in the $350-850 \mathrm{~K}$ column range. Namely, (i) cold and warm winters exhibit respectively higher and lower ozone column depletion, (ii) the ozone loss estimated from MLS is larger than that from the model alone (except in 2005 in $350-550 \mathrm{~K}$ ), and (iii) the modelled loss is larger by about 10-20 DU than the measured depletion in warm winters.

In a study using Match ozonesonde measurements in the Arctic, Harris et al. (2010) derive an accumulated ozone column depletion of 72 DU in 2007 and 65 DU in 2008 in 380$550 \mathrm{~K}$. Both Mimosa-Chim and MLS loss estimations underestimate the Match results in 2007 by $10-15$ DU and overestimate them in 2008 by $15-25$ DU. In contrast to the Match results, our estimations provide comparatively larger ozone loss in the cold winter 2008. The simulated loss in 2006 is in good agreement with that of Feng et al. (2007), who calculate a loss of about $32 \mathrm{DU}$ in early-February in $380-550 \mathrm{~K}$. The comparison of ozone column loss estimates for the Arctic winter 2005 is presented in a separate section as there are several published results available for a discussion. 
Table 3. The vortex averaged $\left(\geq 65^{\circ} \mathrm{EqL}\right.$ ) ozone partial column loss (DU) computed from Mimosa-Chim and MLS data in $350-550 \mathrm{~K}$ and $350-675 \mathrm{~K}$ are compared to various results for the Arctic winter 2005. Individual vortex definition is used by each study. The error estimation provided by the respective studies are given together with the ozone loss values. Here, the column title "Period" represents the time line of individual studies and "Max. Loss" indicates the day on which the maximum ozone depletion is estimated. The column length used for the ozone loss computations are relatively small for the estimates given in italics.

\begin{tabular}{lllccc}
\hline Study & Data & Column & Period & Max. Loss & Loss (DU) \\
\hline This study & MLS & $350-675 \mathrm{~K}$ & December-March & March end & 109 \\
- & MLS & $350-550 \mathrm{~K}$ & December-March & March end & 81 \\
Singleton et al. (2007) & Satellites & $400-550 \mathrm{~K}$ & January/March & March end & $90 \pm 15$ \\
Tsvetkova et al. (2007) & SAGE III & $350-625 \mathrm{~K}$ & January/25 March & 25 March & $116 \pm 10$ \\
Jin et al. (2006) & ACE-FTS & $375-650 \mathrm{~K}$ & 1-7 January/mid-March & 15 March & 116 \\
Rex et al. (2006) & Match & $350-550 \mathrm{~K}$ & January/25 March & 25 March & $127 \pm 21$ \\
von Hobe et al. (2006) & in-situ & $344-460 \mathrm{~K}$ & 7 March & 7 March & $62 \pm$ \\
& Simulations & & & & +17 \\
\hline & Mimosa-Chim & $350-675 \mathrm{~K}$ & December-March & March end & 107 \\
\hline This study & Mimosa-Chim & $350-550 \mathrm{~K}$ & December-March & March end & 91 \\
- & CLAMS & $380-580 \mathrm{~K}$ & January-March & 23 March & $69 \pm 20$ \\
Grooß and Müller (2007) & SLIMCAT & $380-550 \mathrm{~K}$ & December-March & March end & 140 \\
Feng et al. (2007) & & & & & \\
\hline
\end{tabular}

The difference between the partial column loss estimated in $350-550 \mathrm{~K}$ and $350-850 \mathrm{~K}$ (i.e., $\Delta$ Loss $=\operatorname{Loss}_{350}-850 \mathrm{~K}^{-}$ $\operatorname{Loss}_{350-550 \mathrm{~K})}$ averaged over the studied winters is equal to $18.0 \pm 5.2$ and $19.7 \pm 8.6 \mathrm{DU}$ for the MLS observations and Mimosa-Chim simulations respectively. Such a difference, mainly due to the effect of $\mathrm{NO}_{\mathrm{x}}$ chemistry in the middle stratosphere, has to be taken into account when comparing polar ozone loss computed from total ozone observations with that derived from ozone profile measurements/simulations.

\subsubsection{Partial column loss in 2005}

Since the winter 2005 was one of the coldest in the decade, a number of ozone loss estimations based on measurements and simulations have been published. Table 3 compiles the vortex averaged ozone column loss calculated from various data sets. For a better comparison with other results we have also estimated the loss in 350-675 K from both MimosaChim simulations and MLS observations. As shown by the table the loss estimated by different studies generate different results. The Mimosa-Chim analysis shows a good agreement with Singleton et al. (2007), who also compute a similar loss from MLS observations. The Mimosa-Chim/MLS ozone loss in 350-675 K show a good agreement with those from Jin et al. (2006) and Tsvetkova et al. (2007). The larger loss simulated in Feng et al. (2007) is due to the higher vortex descent and accompanied increase in chlorine loading in the lower stratosphere of their model. The ozone loss computation from von Hobe et al. (2006) shows the lowest value among these analyses while that of Rex et al. (2006) provides the largest estimate. The accumulated loss in von Hobe et al. (2006) was estimated on 7 March, which is much ear- lier than in other studies (around $25 \mathrm{March}$ ) and there was a strong vortex and sustained loss afterwards. Also, the loss was estimated only up to $460 \mathrm{~K}$, which is much lower than the column upper limit considered in other studies. Such a discrepancy in the altitude range used for the analyses is one of the reasons for the spread in the results. Another possible reason for the difference is that most works use their own vortex criterion for the ozone column loss estimation.

Regarding the ozone loss derived from various model results, the simulations by Grooß and Müller (2007) provide the lowest estimate. This offset can be due to a different sampling of the vortex by the model grid, as compared to the satellite observations. In order to check this, we averaged the simulated loss over all the model grid points (not only at the footprint of MLS observations) using the same vortex criterion of Grooß and Müller (2007) and obtained a loss of $73 \mathrm{DU}$ in $350-550 \mathrm{~K}$ (our model vertical levels are different). This estimate is in very good agreement with the calculation of Grooß and Müller (2007). Another important fact to note is the sampling of the vortex by the MLS sensor, which is limited to $82^{\circ}$. In contrast, the model grid spans to the full $90^{\circ}$ including the pole. Therefore, the average calculated from the models can cover the area inside the vortex from this additional latitude region of $8^{\circ}\left(\right.$ i.e., $83-90^{\circ} \mathrm{N}$ ) too, and hence, this average can differ from the mean loss estimated at the satellite footprints. In short, the differences in vortex sampling, altitude range, time period and vortex definition of the analyses have to be taken into account when comparing different ozone loss estimations. 


\section{Conclusions}

The evaluation of vortex averaged ozone loss from the model and satellite observations shows large variability in the Arctic winters 2005-2010, in accordance with analyses performed for previous northern winters. The cold winters 2005 and 2008 record the highest loss with peak ozone loss around $475 \mathrm{~K}$. In 2007, the maximum loss is estimated at a higher altitude, around $650 \mathrm{~K}$ and the minimal loss among the winters is obtained in the warm winters 2006 and 2009 . At $475 \mathrm{~K}$, the cumulative ozone loss ranges from $0.7 \mathrm{ppmv}$ in 2006 to $1.5-1.7 \mathrm{ppmv}$ in 2005 . At $675 \mathrm{~K}$ the loss ranges from $0.3-$ $0.5 \mathrm{ppmv}$ in 2009 to $1.3 \mathrm{ppmv}$ in 2005. In general, the ozone loss values derived from the Mimosa-Chim simulations and MLS observations, combined with the model passive tracer, are in good agreement and the differences are mostly within the estimated accuracy of the observations.

It has to be noted that, since there is a large variability in peak ozone loss altitude from one year to the next, analysis or comparison of ozone loss at specific altitudes is neither complete nor well-represented as far as the variability of Arctic winters is concerned. Therefore, care has to be taken while interpreting the ozone loss estimated at specific altitudes, to characterise or compare different winters.

Model runs with specific chemical cycles suggest that the halogen cycles; $\mathrm{ClO}-\mathrm{ClO}$ contributes $\sim 40-50 \%$ and $\mathrm{BrO}-$ $\mathrm{ClO}$ contributes $\sim 30-40 \%$ to the total loss in DecemberFebruary at $475 \mathrm{~K}$. These cycles depend on temperatures in the lower stratosphere, PSCs, heterogeneous reactions on PSCs and thus the Arctic meteorology. The $\mathrm{NO}-\mathrm{NO}_{2}$ cycle is the key mechanism that depletes about $60-75 \%$ of ozone in the middle stratosphere, which is essentially predominant in January-March period. In warm winters, the contribution from $\mathrm{HO}_{\mathrm{x}}$ cycle gradually increases and eventually dominates in the lower stratospheric ozone loss process after the major warming.

The ozone partial column loss estimated in $350-850 \mathrm{~K}$ from Mimosa-Chim calculations at the MLS footprints inside the vortex shows about 109, 42, 80, 98, 53, and $79 \mathrm{DU}$ in 2005, 2006, 2007, 2008, 2009 and 2010, respectively, and are in good agreement with those of the MLS and SAOZ observations within the limits of their error estimations. There is a significant difference $(\sim 19 \pm 7 \mathrm{DU})$ in the ozone column loss estimated between the ranges $350-850$ and $350-550 \mathrm{~K}$. The additional loss above $550 \mathrm{~K}$ is mainly due to $\mathrm{NO}_{\mathrm{x}}$ chemical cycles and should be accounted for while estimating the column loss from ozone profile measurements/simulations. This is particularly important in cold winters with vertically spread ozone depletion (e.g. in 2005) and warm winters with peak ozone loss above $550 \mathrm{~K}$ (e.g. in 2009).
Acknowledgements. The authors would like to thank Cathy Boonne of IPSL/CNRS Paris for the REPROBUS data. They also thank Andrea Pazmino and Julien Gazeaux of CNRS/LATMOS Guyancourt/Paris for their co-operation during this study. They extend their gratitude to the reviewers, Jens-Uwe Grooß and Martin Dameris (the Editor) for their constructive comments on the article that helped to further improve the quality of this article. The MLS data used in this study were acquired as part of the NASA's Earth-Sun System Division and archived and distributed by the Goddard Earth Sciences (GES) Data and Information Services Center (DISC). The work is supported by funds from the ANR/ORACLE- $\mathrm{O}_{3}$ France and the EU SCOUT-O $\mathrm{O}_{3}$ projects.

Edited by: M. Dameris

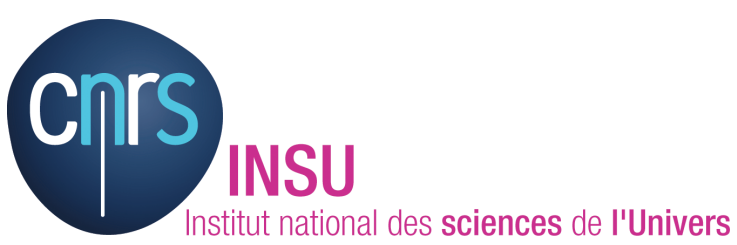

The publication of this article is financed by CNRS-INSU.

\section{References}

Amraoui, L. El, Semane, N., Peuch, V.-H., and Santee, M. L.: Investigation of dynamical processes in the polar stratospheric vortex during the unusually cold winter 2004/2005, Geophys. Res. Lett., 35, L03803, doi:10.1029/2007GL031251, 2008.

Burkholder, J. B., Orlando, J. J., and Howard, C. J.: Ultraviolet absorption cross-sections of $\mathrm{Cl}_{2} \mathrm{O}_{2}$ between 210 and $410 \mathrm{~nm}$, J. Phys. Chem., 94, 687-695, 1990.

Butz, A., Bösch, H., Camy-Peyret, C., Dorf, M., Engel, A., Payan, S., and Pfeilsticker, K.: Observational constraints on the kinetics of the $\mathrm{ClO}-\mathrm{BrO}$ and $\mathrm{ClO}-\mathrm{ClO}$ ozone loss cycles in the Arctic winter stratosphere, Geophys. Res. Lett., 34, L05801, doi:10.1029/2006GL028718, 2007.

Davies, S., Chipperfield, M. P., Carslaw, K. S., et al.: Modelling the effect of denitrification on Arctic ozone depletion during winter 1999/2000, J. Geophys. Res., 107, 8322, doi:10.1029/2001JD000445, 2002.

Feng, W., Chipperfield, M. P., Davies, S., von der Gathen, P., Kyrö, E., Volk, C. M., Ulanovsky, A., and Belyaev, G.: Large chemical ozone loss in 2004/2005 Arctic winter/spring, Geophys. Res. Lett., 34, L09803, doi:10.1029/2006GL029098, 2007.

Flury, T., Hocke, K., Haefele, A., Kämpfer, N., and Lehmann, R.: Ozone depletion, water vapor increase, and PSC generation at mid-latitudes by the 2008 major stratospheric warming, J. Geophys. Res., 114, D18302, doi:10.1029/2009JD011940, 2009.

Frieler, K., Rex, M., Salawitch, R. J., Canty, T., Streibel, M., Stimpfle, R. M., Pfeilsticker, K., Dorf, M., Weisenstein, D. K., and Godin-Beekmann, S.: Toward a better quantitative understanding of polar stratospheric ozone loss, Geophys. Res. Lett., 33, L10812, doi:10.1029/2005GL025466, 2006.

Froidevaux, L., Livesey, N. G., Read, W. G., et al: Early validation analyses of atmospheric profiles from EOS MLS on the Aura satellite, IEEE Trans. Geosci. Remote Sens., 44, 1106-1121, 2006. 
Goutail, F., Pommereau, J.-P., Lefèvre, F., van Roozendael, M., Andersen, S. B., Kåstad Høiskar, B.-A., Dorokhov, V., Kyrö, E., Chipperfield, M. P., and Feng, W.: Early unusual ozone loss during the Arctic winter 2002/2003 compared to other winters, Atmos. Chem. Phys., 5, 665-677, doi:10.5194/acp-5-665-2005, 2005.

Goutail, F., Lefèvre, F., Kuttippurath, J., Pazmiño, A., Pommereau, J.-P., Chipperfield, M., Feng, W., Van Roozendael, M., Eriksen, P., Stebel, K., Dorokhov, V., Kyro, E., Adams, C., and Strong, K.: Total ozone loss during the 2009/2010 Arctic winter and comparison to previous years, Geophys. Res. Abs., 12, EGU2010-3725$2,2010$.

Grooß, J.-U., Günther, G., Müller, R., Konopka, P., Bausch, S., Schlager, H., Voigt, C., Volk, C. M., and Toon, G. C.: Simulation of denitrification and ozone loss for the Arctic winter 2002/2003, Atmos. Chem. Phys., 5, 1437-1448, doi:10.5194/acp-5-14372005, 2005a.

Grooß, J.-U., Konopka, P., and Müller, R.: Ozone chemistry during the 2002 Antarctic vortex split, J. Atmos. Sci., 62, 860-870, $2005 b$.

Grooß, J.-U. and Müller, R.: Simulation of ozone loss in Arctic winter 2004/2005, Geophys. Res. Lett., 34, L05804, doi:10.1029/2006GL028901, 2007.

Hanson, D. and Mauersberger, K.: Laboratory studies of the nitric acid trihydrate: implications for the south polar stratosphere, Geophys. Res. Lett., 15, 855-858, 1988.

Harris, N. R. P., Lehmann, R., Rex, M., and von der Gathen, P.: A closer look at Arctic ozone loss and polar stratospheric clouds, Atmos. Chem. Phys., 10, 8499-8510, doi:10.5194/acp-10-84992010, 2010.

Hauchecorne, A., Godin, S., Marchand, M., Heese, B., and Souprayen, C.: Quantification of the transport of chemical constituents from the polar vortex to mid-latitudes in the lower stratosphere using the high-resolution advection model MIMOSA and effective diffusivity, J. Geophys. Res., 107, 8289, doi:10.1029/2001JD000491, 2002.

Jackson, D. R., and Orsolini, Y. J.: Estimation of Arctic ozone loss in winter 2004/2005 based on assimilation of EOS MLS and SBUV/2 observations, Q. J. Roy. Meteorol. Soc., 134, 18331841, 2008.

Jin, J. J., Semeniuk, K., Manney, G. L., Jonsson, A. I., Beagley, S. R., McConnell, J. C., Dufour, G., Nassar, R., Boone, C. D., Walker, K. A.,Bernath, P. F., and Rinsland, C. P.: Severe Arctic ozone loss in the winter 2004/2005: Observations from ACE-FTS, Geophys. Res. Lett., 33, L15801, doi:10.1029/2006GL026752, 2006.

Konopka, P., Engel, A., Funke, B., et al.: Ozone loss driven by nitrogen oxides and triggered by stratospheric warmings can outweigh the effect of halogens, J. Geophys. Res., 112, D05105, doi:10.1029/2006JD007064, 2007.

Kuttippurath, J., Godin-Beekmann, S., Lefèvre, F., and Pazmiño, A.: Ozone depletion in the Arctic winter 2007/08, Int. J. Remote sens., 30, 4071-4082, doi:10.1080/01431160902821965, 2009.

Kuttippurath, J., Godin-Beekmann, S., Lefèvre, F., and Nikulin, G.: Dynamics of the exceptional warming events during the recent Arctic winters, Geophys. Res. Abs., 12, EGU2010-5499, 2010.

Lefèvre, F., Brasseur, G. P., Folkins, I., Smith, A. K., and Simon, P.: Chemistry of the 1991/1992 stratospheric winter: three dimensional model simulation, J. Geophys. Res., 99, 8183-8195,
1994.

Luo, B., Carslaw, K. S., Peter, T., and Clegg, S. L.: Vapour pressures of $\mathrm{H}_{2} \mathrm{SO}_{4} / \mathrm{HNO}_{3} / \mathrm{HCl} / \mathrm{HBr} / \mathrm{H}_{2} \mathrm{O}$ solutions to low stratospheric temperatures, Geophys. Res. Lett., 22, 247-250, 1995.

MacKenzie, I., Harwood, R., Froidevaux, L., Read, W., and Waters, J.: Chemical loss of polar vortex ozone inferred from UARS MLS measurements of $\mathrm{ClO}$ during the Arctic and Antarctic late winters of 1993, J. Geophys. Res., 101(D9), 14505-14518, 1996.

Manney, G. L., Santee, M. L., Froidevaux, L., Hoppel, K., Livesey, N. J., and Waters, J. W.: EOS MLS observations of ozone loss in the 2004-2005 Arctic winter, Geophys. Res. Lett., 33, L04802, doi:10.1029/2005GL024494, 2006.

Manney, G. L., Daffer, W. H., Zawodny, J. M., et al.: Solar Occultation satellite data and derived meteorological products: sampling issues and comparisons with Aura MLS, J. Geophys. Res., 112, D24S50, doi:10.1029/2007JD008709, 2007.

Marchand, M., Bekki, S., Pazmino, A., Lefèvre, F., GodinBeekmann, S., and Hauchecorne, A.: Model simulations of the impact of the 2002 Antarctic ozone hole on the Midlatitudes, J. Atmos. Sci., 62, 871-884, 2005.

Müller, R., Grooß, J.-U., Lemmen, C., Heinze, D., Dameris, M., and Bodeker, G.: Simple measures of ozone depletion in the polar stratosphere, Atmos. Chem. Phys., 8, 251-264, doi:10.5194/acp8-251-2008, 2008.

Newman, P. A., Harris, N. R. P., Adriani, A., et al.: An overview of the SOLVE/THESEO 2000 campaign, J. Geophys. Res., 107(D20), 8259, doi:10.1029/2001JD001303, 2002.

Papanastasiou, D. K., Papadimitriou, V. C., Fahey, D. W., and Burkholder, J. B.: UV absorption spectrum of the $\mathrm{ClO}$ dimer $\left(\mathrm{Cl}_{2} \mathrm{O}_{2}\right)$ between 200 and $420 \mathrm{~nm}$, J. Phys. Chem. A, 113, 13711-13726, 2009.

Rex, M., Salawitch, R. J., Deckelmann, H., et al.: Arctic winter 2005: Implications for stratospheric ozone loss and climate change, Geophys. Res. Lett., 33, L23808, doi:10.1029/2006GL026731, 2006.

Rösevall, J., Murtagh, D. P., and Urban, J.: Ozone depletion in the 2006/2007 Arctic winter, Geophys. Res. Lett., 34, L21809, doi:10.1029/2007GL030620, 2007.

Rösevall, J., Murtagh, D. P., Urban, J., Feng, W., Eriksson, P., and Brohede, S.: A study of ozone depletion in the 2004/2005 Arctic winter based on data from Odin/SMR and Aura/MLS, J. Geophys. Res., 113, D13301, doi:10.1029/2007JD009560, 2008.

Sander, S. P., Friedl, R. R., Golden, D. M., et al.: Chemical kinetics and photochemical data for use in atmospheric studies, Eval. 15, JPL Publ. 06-2, Jet Propul. Lab., Pasadena, USA, 2006.

Santee, M. L., Lambert, A., Read, W. G., Livesey, N. J., Manney, G. L., Cofield, R. E., Cuddy, D. T., Daffer, W. H., Drouin, B. J., Froidevaux, L., Fuller, R .A., Jarnot, R. F., Knosp, B. W., Perun, V. S., Snyder, W. V., Stek, P. C., Thurstans, R. P., Wagner, P. A., Waters, J. W., Connor, B., Urban, J., Murtagh, D., Ricaud, P., Barrett, B., Kleinböhl, A., Kuttippurath, J., Küllmann, H., von Hobe, M., Toon, G. C., and Stachnik, R. A.: Validation of the Aura Microwave Limb Sounder ClO measurements, J. Geophys. Res., 113, D15S22, doi:10.1029/2007JD008762, 2008.

Shine, K. P.: The middle atmosphere in the absence of dynamical heat fluxes, Q. J. Roy. Meteorol. Soc., 113(8322), 603-633, 1987.

Singleton, C. S., Randall, C. E., Harvey, V. L., et al.: Quantifying Arctic ozone loss during the 2004-2005 winter using satellite 
observations and a chemical transport model, J. Geophys. Res., 112, D07304, doi:10.1029/2006JD007463, 2007.

Tripathi, O. P., Godin-Beekmann, S., Lefèvre, F., et al.: High resolution simulation of recent Arctic and Antarctic stratospheric chemical ozone loss compared to observations, J. Atmos. Chem., 55, 205-226, 2006.

Tripathi, O. P., Godin-Beekmann, S., Lefèvre, F., et al.: Comparison of polar ozone loss rates simulated by one-dimensional and three-dimensional models with Match observations in recent Antarctic and Arctic winters, J. Geophys. Res., 112, D12307, doi:10.1029/2006JD008370, 2007.

Tsvetkova, N. D., Yushkov, V. A., Luk'yanov, A. N., Dorokhov, V. M., and Nakane, H.: Record-breaking chemical destruction of ozone in the arctic during the winter of 2004/2005, Izvestiya Atmos. Ocean. Phys., 43, 592-598, 2007.

Vogel, B., Konopka, P., Grooß, J.-U., Müller, R., Funke, B., LópezPuertas, M., Reddmann, T., Stiller, G., von Clarmann, T., and Riese, M.: Model simulations of stratospheric ozone loss caused by enhanced mesospheric $\mathrm{NO}_{\mathrm{x}}$ during Arctic Winter 2003/2004, Atmos. Chem. Phys., 8, 5279-5293, doi:10.5194/acp-8-52792008, 2008. von Hobe, M., Ulanovskya, A., Volk, C. M., et al.: Severe ozone depletion in the cold Arctic winter 2004-05, Geophys. Res. Lett., 33, L17815, doi:10.1029/2006GL026945, 2006.

World Meteorological Organisation (WMO): Scientific Assessment of Ozone Depletion: 2006, Global Ozone Monitoring and Research Project-Report No: 50, Geneva, Switzerland, 572 pp., 2007.

Woyke, T., Müller, R., Stroh, F., McKenna, D. S., Engel, A., Margitan, J. J., Rex, M., and Carslaw, K. S.: A test of our understanding of the ozone chemistry in the Arctic polar vortex based on in situ measurements of $\mathrm{ClO}, \mathrm{BrO}$, and $\mathrm{O}_{3}$ in the 1994/1995 winter, J. Geophys. Res., 104(D15), 18755-18768, 1999.

Wu, J. and Dessler, A. E.: Comparisons between measurements and models of Antarctic ozone loss, J. Geophys. Res., 106(D3), 3195-3201, 2001. 